\title{
Increased flow of testicular blood plasma during local heating of the testes of rams
}

\author{
R. Mieusset*, S. F. Sowerbutts, J. L. Zupp and B. P. Setchell \\ Department of Animal Sciences, Waite Agricultural Research Institute, University of Adelaide, \\ Glen Osmond, SA 5064, Australia
}

\begin{abstract}
Summary. After removal of the scrotal skin, one testis of each of 12 adult anaesthetized rams was kept at $33^{\circ} \mathrm{C}$ for $60 \mathrm{~min}$, then heated either to $36^{\circ} \mathrm{C}$ for $60 \mathrm{~min}$ and then to $39^{\circ} \mathrm{C}$ for $60 \mathrm{~min}$, or to $36^{\circ} \mathrm{C}$ for $120 \mathrm{~min}$ and then returned to $33^{\circ} \mathrm{C}$ for $100 \mathrm{~min}$, while the other testis was maintained at $33^{\circ} \mathrm{C}$. Flow of testicular blood plasma was measured every $10 \mathrm{~min}$ using the technique of dilution of sodium $p$-aminohippurate.

When the temperature of the testis was raised to $36^{\circ} \mathrm{C}$, flow of blood plasma gradually increased and reached a higher than normal rate at the end of the first hour, without any further increase during the second hour. The increase in mean flow rate was $25 \cdot 8 \pm 3 \cdot 4 \%$ (mean $\pm \mathrm{SEM}$ ) during the second hour at $36^{\circ} \mathrm{C}$, and $77 \cdot 1 \pm 12 \cdot 8 \%$ during the hour at $39^{\circ} \mathrm{C}$, compared with the respective values at $33^{\circ} \mathrm{C}$. No significant changes were seen in testicular lymph flow determined by collection for $10 \mathrm{~min}$ in four rams at $36^{\circ} \mathrm{C}(60 \mathrm{~min})$ and then at $39^{\circ} \mathrm{C}(60 \mathrm{~min})$.

These results are different from those from earlier studies in which total blood flow was unchanged when the scrotum and testes were heated. The difference could be related either to lack of heating of the scrotum or to the lower temperatures used in the present study. Changes in the flow of arterial blood bypassing the testis through arterio--venous anastomoses in the spermatic cord might be involved, as a result of heating of the testes.
\end{abstract}

Keywords: testis; temperature; lymph; blood flow; sheep

\section{Introduction}

Most studies suggest that heating the scrotum of rams to a temperature similar to or slightly below body temperature does not have any marked effect on testicular blood flow, whether measured as total flow (Waites \& Setchell, 1964; Godinho \& Setchell, 1975), or as nutrient or capillary flow, which is about two-thirds of the total (Setchell et al., 1966; Godinho \& Setchell, 1975). However, in one study, with Merino rams selected for a low degree of skin wrinkle, there were appreciable increases in testicular capillary blood flow when the scrotum was heated to 37 or $40^{\circ} \mathrm{C}$ for $150 \mathrm{~min}$ (Fowler \& Setchell, 1971). When the scrotum of Southdown rams was heated to $39 \cdot 5^{\circ} \mathrm{C}$ for 7 days, capillary flow increased on Days 1 and 3 (Sand et al., 1971). All the techniques used in these experiments have a number of disadvantages, and either measure mean flow over $20-40 \mathrm{~min}$, or give only a single measurement for each animal (see Setchell \& Brooks, 1988; Waites \& Setchell, 1990 for a fuller comparison of the various methods).

This question merits re-investigation for a number of reasons. First, there is now conclusive anatomical evidence for the existence of arterio-venous anastomoses in the spermatic cord (Wensing et al., 1981; Hees et al., 1984), through which up to $60 \%$ of the arterial blood flows, thus bypassing the testis (Noordhuizen-Stassen et al., 1985). Nothing has been reported on the control

*Present address: Centre de Stérilité Masculine, Hôpital La Grave, 31052 Toulouse Cedex, France. 
of these anastomoses and they could influence the amount of blood actually reaching the testes. Second, there is now abundant evidence that there are temperature receptors in the scrotal skin, stimulation of which induces localized relaxation of the tunica dartos, synchronous discharge of sweat from the scrotal skin and generalized thermoregulatory responses, such as panting and changes in metabolic rate, which are sufficient to lower core temperature considerably (Waites, 1961, 1962; Waites \& Voglmayr, 1963). The input from these receptors is transmitted through the spinal cord to the brain, where the information is processed in the thalamus, hypothalamus and cortex, to produce the responses already mentioned and possibly other effects (see Waites, 1976; Setchell, 1978 and Setchell \& Brooks, 1988 for a fuller discussion of the nervous pathways and responses involved). Third, a technique is now available (Laurie \& Setchell, 1979) that allows virtually continuous measurement of flow of testicular blood, with no limits to the number of observations that can be made on any animal.

Consequently, we have re-examined the relationship between testicular temperature and blood flow, under conditions where temperature of the scrotal skin was not altered. The aim of the study was to evaluate flow of total testicular blood when testis temperature was increased to physiological values (i.e. $36^{\circ} \mathrm{C}$ or $39^{\circ} \mathrm{C}$ ) and then brought back to its normal value (i.e. $33^{\circ} \mathrm{C}$ ). Flow of testicular lymph was also monitored, as it has been reported to increase when the scrotum was heated (Cowie et al., 1964), although this is more likely than blood flow to be affected by changes in vascular permeability.

\section{Materials and Methods}

\section{Animals}

Twelve aduit Australian Merino rams aged between 3 and 5 years and weighing between 65 and $75 \mathrm{~kg}$ were used. Three were anaesthetized with $12 \mathrm{mg}$ pentobarbitone sodium $/ \mathrm{kg}$ intravenously (Sigma Chemicals, St Louis, MO, USA) and nine with $1.5 \mathrm{~g}$ urethane $/ \mathrm{kg}$ intravenously (ethyl carbamate, Ajax Chemicals, Sydney, Australia) and maintained with further doses of the same anaesthetic as necessary through an intravenous catheter.

\section{Surgical procedure}

An anterior midline incision was made in the scrotal skin, so that the scrotum could be completely reflected away from the testes. Through a short incision in the tunica vaginalis, the head of the epididymis was reflected and a tapered polythene catheter $(0.5 \mathrm{~mm}$ o.d., $0.2 \mathrm{~mm}$ i.d., Dural Plastic, NSW, Australia) was introduced through a needle puncture into a vein on the surface of the exposed testis. A thermal probe was placed between the testis and the tunica vaginalis, which was then sutured carefully and the same procedure was repeated on the other testis.

A second incision was made in the tunica near the inguinal canal and a polyvinyl chloride catheter $(1.2 \mathrm{~mm}$ o.d., $0.8 \mathrm{~mm}$ i.d.) was inserted through a vein at the top of the pampiniform plexus and advanced about $12 \mathrm{~cm}$, so that its tip lay in the main internal spermatic vein. In four animals, the lymphatic vessels in the spermatic cord were located through the same incision, and one of the larger ones cannulated with a $U$-shaped catheter filled with 100 iu heparinsaline/ml, after the rest had been ligated. The tunica was then sutured carefully and the same procedure repeated on the other testis.

Each testis was placed in a small plastic bag, and the ram, still anaesthetized, was supported in an upright position in a sling, and infused with $1 \mathrm{ml}$ of $0.9 \%$ sodium chloride/min through a catheter in the recurrent tarsal vein throughout the experiment. In each animal, the testes in their plastic bags were simultaneously immersed in two containers through which thermoregulated water was circulated. Temperatures of the testes, rectum, water bath and room were recorded every $5 \mathrm{~min}$; at the end of the experiment, the rams were castrated and the testes weighed.

\section{Measurements of flow of testicular blood and lymph}

Flow of testicular blood was measured by continuous infusion of $0.1 \mathrm{ml}$ sodium $p$-aminohippurate $/ \mathrm{min}(2 \%)$ with a peristaltic pump (Gilson Medical Electronics, France) into the catheter in the testicular vein and sampling blood every $10 \mathrm{~min}$ from the catheter above the pampiniform plexus, which served as a mixing system (Laurie \& Setchell, 1979). The concentration of sodium $p$-aminohippurate in blood plasma separated by centrifugation $(600 \mathrm{~g}$ for $15 \mathrm{~min}$ at $4^{\circ} \mathrm{C}$ ) was determined by the method of Bratten \& Marshall (1939) and plașma flow was estimated from the equation: plasma flow $(\mathrm{ml} / \mathrm{min})=$ infusion rate $(\mathrm{mg} / \mathrm{min}) /[$ spermatic venous - jugular concentrations $(\mathrm{mg} / \mathrm{ml})$ ] Lymph was collected from the catheter in some rams into weighed containers which were changed every 10 min. 


\section{Heating programme}

One testis (the left and right in alternate experiments) was maintained in water at $33^{\circ} \mathrm{C}$ throughout the experiment. The contralateral testis was exposed to water at $33^{\circ} \mathrm{C}$ for $60 \mathrm{~min}$ and then either at $36^{\circ} \mathrm{C}$ for $60 \mathrm{~min}$, followed by $39^{\circ} \mathrm{C}$ for $60 \mathrm{~min}(n=5)$, or at $36^{\circ} \mathrm{C}$ for $120 \mathrm{~min}(n=7)$, followed by $33^{\circ} \mathrm{C}$ for $100 \mathrm{~min}(n=5$ of these 7$)$. Experiments differed according to the duration and the water temperature to which the contralateral testis was submitted, as follows:

Expt $1: n=12 ; 33^{\circ} \mathrm{C}$ for $60 \mathrm{~min}$ followed by $36^{\circ} \mathrm{C}$ for $60 \mathrm{~min}$.

Expt $2: n=7$ (of the 12 in Expt 1); a second $60 \mathrm{~min}$ at $36^{\circ} \mathrm{C}$ at the end of the Expt 1 schedule.

Expt 3: $n=5$ (of the 7 in Expt 2); $100 \mathrm{~min}$ at $33^{\circ} \mathrm{C}$ at the end of the Expt 2 schedule.

Expt 4: $n=5$ (the rest of the 12 in Expt 1 ); $39^{\circ} \mathrm{C}$ for $60 \mathrm{~min}$ at the end of the Expt 1 schedule. Lymph flow was measured in four of these five rams.

\section{Statistical analysis}

Comparisons were made between control and heated testes by unpaired $t$-test, and between the same testis at different temperatures by paired $t$-test.

\section{Results}

\section{Experiment 1}

When a testis was heated to $36^{\circ} \mathrm{C}$ for $60 \mathrm{~min}$, mean flow of testicular plasma rose from $89.4 \pm 1.9 \mu \mathrm{l} / \mathrm{g}$ per min (mean \pm SEM) to $109.8 \pm 5.7 \mu \mathrm{l} / \mathrm{g}$ per min during the hour of heating $(P<0.03)$, whereas the mean plasma flow through the control testis did not change $(89.3 \pm 1.9 \mu 1 / \mathrm{g}$ per $\mathrm{min}$ in the first hour, $90 \cdot 1 \pm 2 \cdot 0 \mu \mathrm{l} / \mathrm{g}$ per $\mathrm{min}$ in the second; heated versus control in the second hour: $P<0.01$ ). However, although testicular temperature rose promptly when the temperature of the circulated water was altered, the change in blood flow was more gradual, continuing to increase for most of the hour of heating (Fig. 1).

\section{Experiment 2}

When the testis was maintained at $36^{\circ} \mathrm{C}$ for a second hour, it was apparent that only minor further increases in flow of testicular blood occurred (Fig. 2), although, because of the slow initial increase, the value in the third hour $(114.1 \pm 1.6 \mu \mathrm{l} / \mathrm{g}$ per min) was slightly, but significantly, higher $(P<0.05)$ than in the second hour $(103.3 \pm 3.9 \mu \mathrm{l} / \mathrm{g}$ per min). Values for the second hour, the third hour and the second and third hours combined $(108.7 \pm 2.6 \mu \mathrm{l} / \mathrm{g}$ per $\mathrm{min})$ were significantly higher than in the unheated testis $(P<0.01)$ and the preheating value for the heated testis $(P<0.02$ for hour 2 and for hours 2 and 3 combined; $P<0.001$ for hour 3 ). Compared with the $33^{\circ} \mathrm{C}$ value, the mean increase in the flow of blood plasma during the second hour at $36^{\circ} \mathrm{C}$ was $25.8 \pm 3.4 \%$; flow through the unheated testis did not change $(75.8 \pm 0.8,77 \cdot 3 \pm 1.2$ and $74.6 \pm 0.8 \mu \mathrm{l} / \mathrm{g}$ per min for the first, second and third hours, respectively).

\section{Experiment 3}

In the five rams in which measurements were continued for a further 100 min with the testis returned to $33^{\circ} \mathrm{C}$, testis blood flow of the heated side fell back to control values during the $40 \mathrm{~min}$ after the temperature changed (Fig. 3), but, over the last hour, the value $(68.7 \pm 2.0 \mu \mathrm{l} / \mathrm{g}$ per min) was significantly lower $(P<0.01)$ than the pre-heating value $(77.6 \pm 1.4 \mu \mathrm{l} / \mathrm{g}$ per $\mathrm{min})$. Blood flow through the unheated testis did not change $(73 \cdot 3 \pm 1 \cdot 6,73 \cdot 3 \pm 0 \cdot 8,69 \cdot 6 \pm 0 \cdot 6$ and $70 \cdot 5 \pm 1 \cdot 2 \mu \mathrm{l} / \mathrm{g}$ per min in the first, second, third hours and the final $100 \mathrm{~min}$, respectively). 

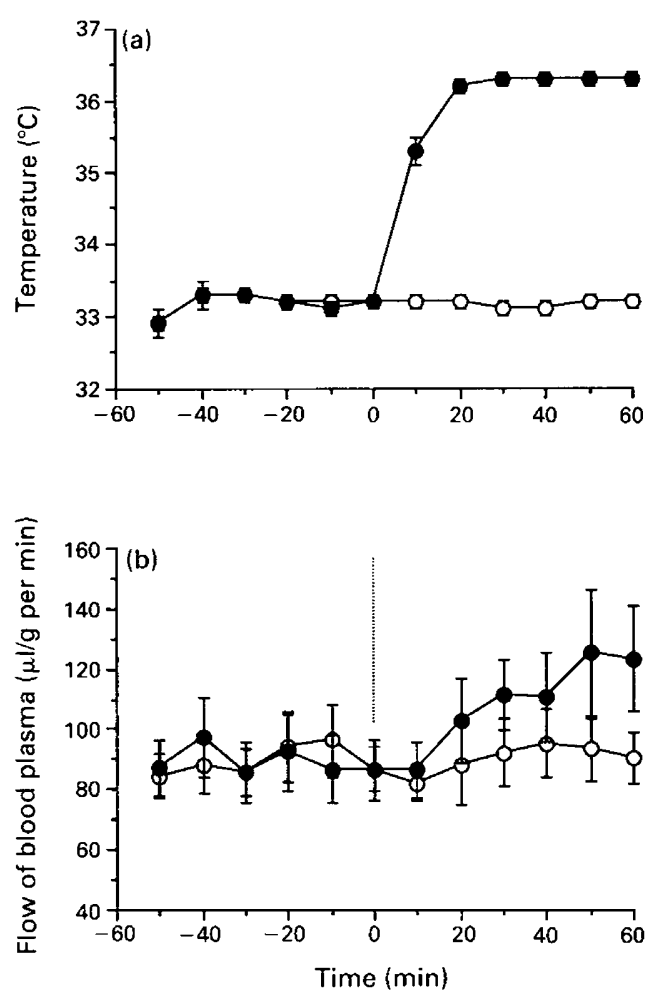

Fig. 1. Temperature (a) and flow of blood plasma (b) in control testes at $33^{\circ} \mathrm{C}(\mathrm{O})$ and in testes at $33^{\circ} \mathrm{C}$ for $60 \mathrm{~min}$ and then heated at $36^{\circ} \mathrm{C}$ for $60 \mathrm{~min}(\bullet)$; (Expt 1 ; mean $\pm \mathrm{SEM}, n=12$ rams).

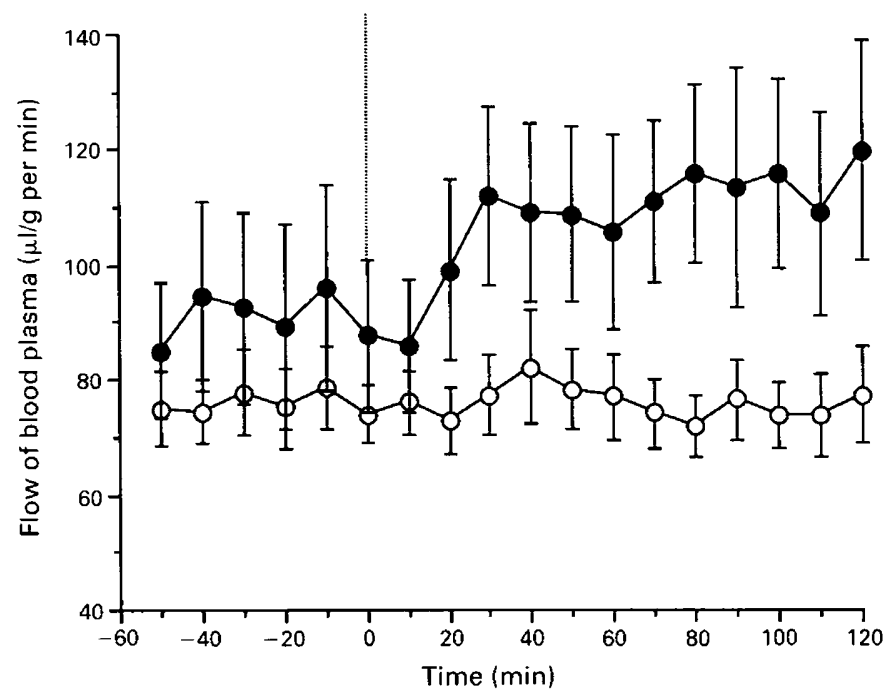

Fig. 2. Flow of blood plasma (mean \pm SEM) in control testes at $33^{\circ} \mathrm{C}(\mathrm{O})$ and in testes at $33^{\circ} \mathrm{C}$ for $60 \mathrm{~min}$ and then heated at $36^{\circ} \mathrm{C}$ for $120 \mathrm{~min}(\bigcirc)$ (Expt $2 ; n=7 \mathrm{rams}$ ). 


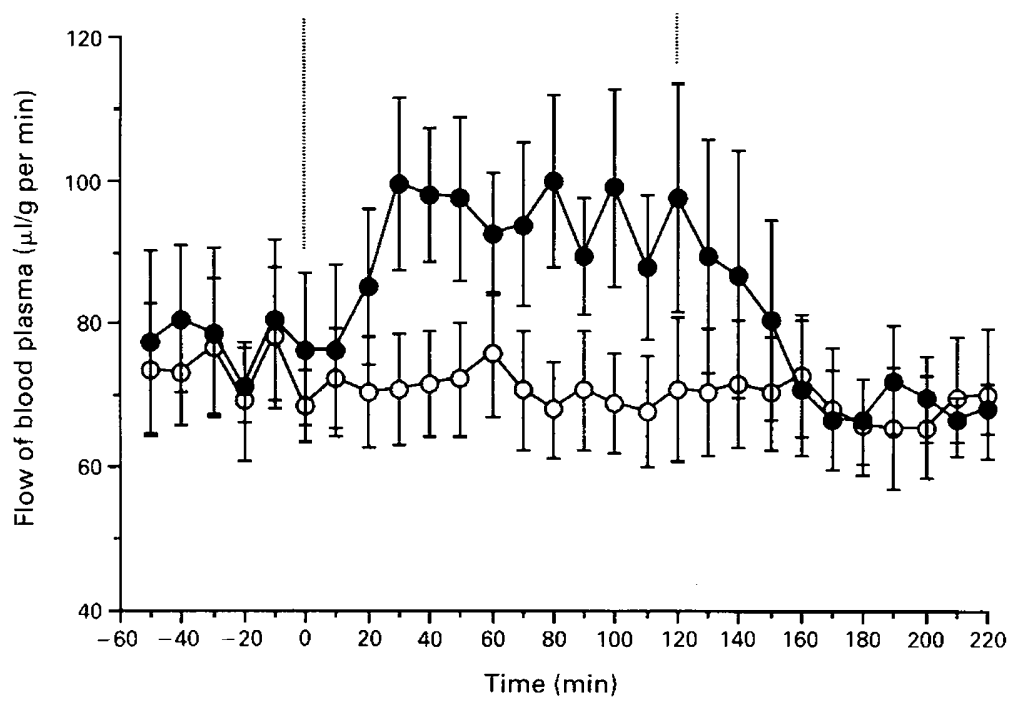

Fig. 3. Flow of blood plasma (mean \pm SEM) in control testes at $33^{\circ} \mathrm{C}(\mathrm{O})$ and in testes at $33^{\circ} \mathrm{C}$ for $60 \mathrm{~min}, 36^{\circ} \mathrm{C}$ for $120 \mathrm{~min}$ and $33^{\circ} \mathrm{C}$ for $100 \mathrm{~min}(\bigcirc)$; (Expt $3 ; n=5$ of the seven rams of Expt 2).

\section{Experiment 4}

In the five rams in which testicular temperature was raised to $39^{\circ} \mathrm{C}$ after an hour at $36^{\circ} \mathrm{C}$, the higher temperature did not produce any further obvious increase in testicular blood flow (Fig. 4), whereas mean flows at $36^{\circ} \mathrm{C}(118.9 \pm 8.9 \mu \mathrm{l} / \mathrm{g}$ per min $)$ and $39^{\circ} \mathrm{C}(151.6 \pm 4.9 \mu \mathrm{l} / \mathrm{g}$ per min) were both significantly greater $\left(P<0.05\right.$ and $P<0.001$, respectively) than flow in that testis at $33^{\circ} \mathrm{C}$ $(87.2 \pm 2.5 \mu \mathrm{l} / \mathrm{g}$ per $\mathrm{min})$. The value at $39^{\circ} \mathrm{C}$ was significantly $(P<0.03)$ higher than at $36^{\circ} \mathrm{C}$, but again this may have been due to the slow change in the first hour of heating. However, in these rams, mean blood flow in the unheated testis in the first hour was slightly, but significantly, higher $(107.4 \pm 4.0 \mu \mathrm{l} / \mathrm{g}$ per min, $P<0.01)$ than in the contralateral testes and, although it did not change when the other testis was heated $(107.5 \pm 3.8$ and $113.8 \pm 3.2 \mu \mathrm{l} / \mathrm{g}$ per min in the second and third hours), mean blood flow in the heated testis was significantly $(P<0.001)$ higher than in the control testis only in the hour at $39^{\circ} \mathrm{C}$. Compared with the $33^{\circ} \mathrm{C}$ value, the mean increase in the flow of blood plasma during the hour at $39^{\circ} \mathrm{C}$ was $77 \cdot 1 \pm 12 \cdot 8 \%$; blood flow at the higher temperatures was more variable, as indicated by the larger standard errors, as shown in the graphs.

There was a great variation in lymph flow from one testis to another, as shown by standard error bars (Fig. 5). At $33^{\circ} \mathrm{C}$, mean flow in the control testes was lower than in the experimental testes, but this difference was not significant. No statistically significant changes were seen in flow of testicular lymph in the four rams from which lymph was collected and in which one testis was heated to $36^{\circ} \mathrm{C}$ for an hour and then to $39^{\circ} \mathrm{C}$ for a similar period (Fig. 5).

\section{Discussion}

Values of flow of testicular blood obtained with the present technique at normal testis temperature in rams $(89.4 \pm 1.9$ and $89.3 \pm 1.9 \mu \mathrm{l} / \mathrm{g}$ per min for 12 control and 12 experiment testes, respectively) were similar to those reported with other techniques $(99.6 \mu \mathrm{l} / \mathrm{g}$ per min, Waites \& Setchell, 1964; and $110 \mu \mathrm{l} / \mathrm{g}$ per min, Setchell et al., 1964), but slightly lower than those measured electromagnetically $(130 \pm 1.0 \mu \mathrm{l} / \mathrm{g}$ per min, Noordhuizen-Stassen et al., 1985).

It is clear from the present results that increases in total blood plasma flow do occur when the temperature of the testis is raised to $36^{\circ}$ or $39^{\circ} \mathrm{C}$, without altering the temperature of the scrotal 


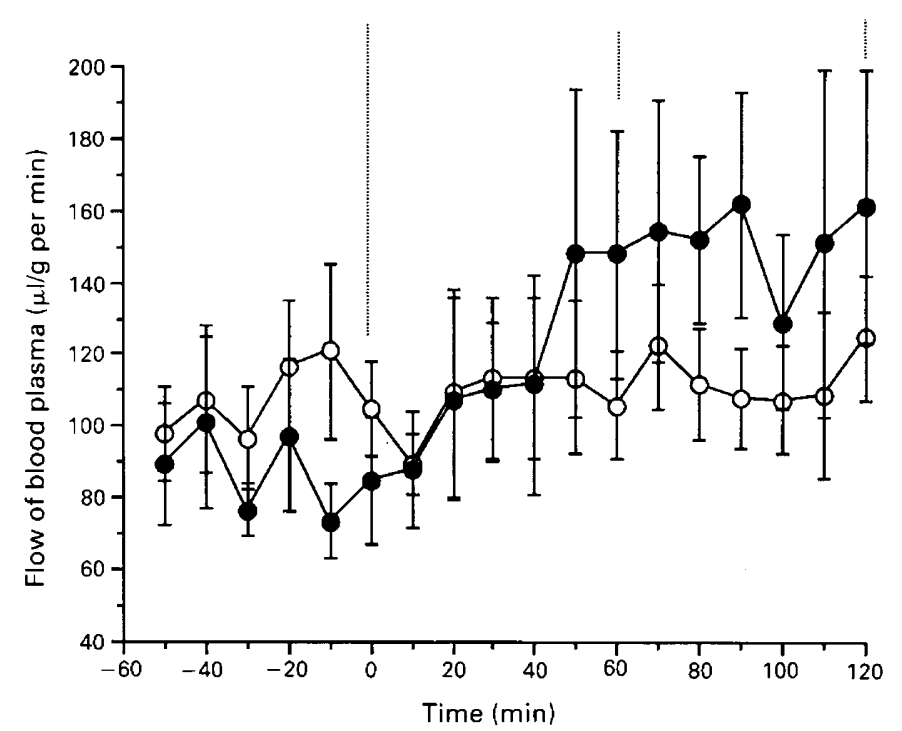

Fig. 4. Flow of blood plasma (mean \pm SEM) in control testes at $33^{\circ} \mathrm{C}(\mathrm{O})$ and in testes at $33^{\circ} \mathrm{C}$ for $60 \mathrm{~min}, 36^{\circ} \mathrm{C}$ for $60 \mathrm{~min}$ and $39^{\circ} \mathrm{C}$ for $60 \mathrm{~min}$ (O) (Expt $4 ; n=5 \mathrm{rams}$ ).

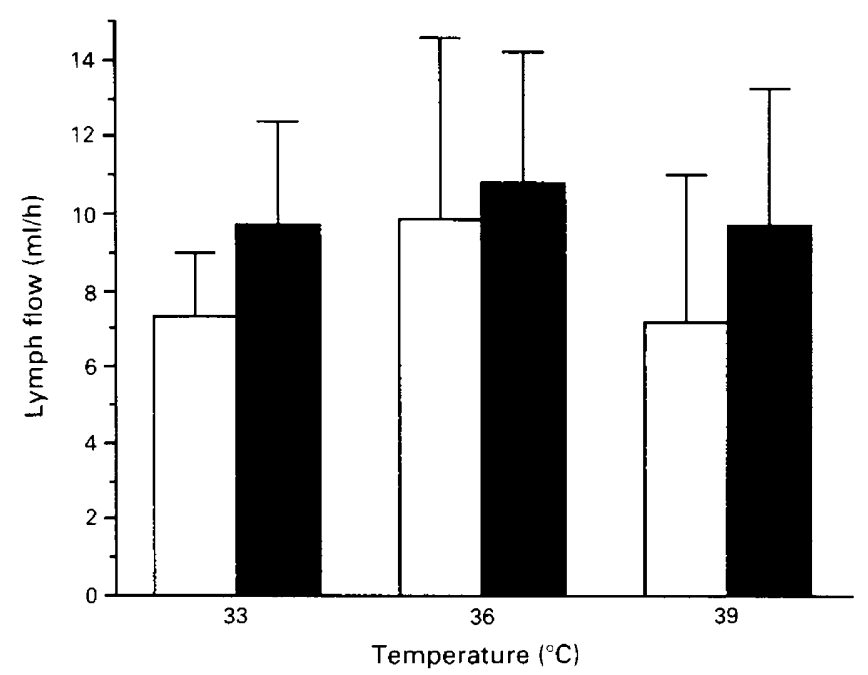

Fig. 5. Flow of testicular lymph (mean \pm SFM) in control $(\square)$ and heated ( $\boldsymbol{\square})$ testes in four of the five rams of Expt 4.

skin. Why do these results differ from earlier results showing no modifications in total blood flow when the scrotum of rams was heated (Waites \& Setchell, 1964; Godinho \& Setchell, 1975)? The technique for measuring blood flow used in the present study has several advantages, particularly in that it allows many repeated estimates to be made at frequent intervals, whereas the techniques used earlier, dilution of a marker which accumulated in the circulation (Godinho \& Setchell, 1975), or the Fick principle with the uptake of a diffusible soluble marker (Waites \& Setchell, 1964), gave average values over $10-30 \mathrm{~min}$ and allowed only one measurement on each animal at each temperature. Besides these technical differences, only four animals were used in the experiment 
group in the earlier studies; but flow of testicular blood was measured after the scrotum had been heated for $3 \mathrm{~h}$ (Waites \& Setchell, 1964) or for 90-120 min (Godinho \& Setchell, 1975), that is to say the results should not have been affected by the delay in the flow response seen in the present experiments.

The main differences lie first in the higher temperatures used in the earlier studies $\left(40-42^{\circ} \mathrm{C}\right.$ compared with 36 and $39^{\circ} \mathrm{C}$ ), which can induce many generalized responses (Waites et al., 1973) possibly interfering with testicular blood flow. Second, the scrotum with the testes inside was heated, and not just the testes as in the present study. Synchronized discharges of scrotal sweat begin when scrotal skin temperature reaches about $35.5^{\circ} \mathrm{C}$, and many generalized physiological reactions occur as a result of scrotal heating (Waites, 1962). But most of them can be blocked by local anaesthesia of the nerves from the scrotum (Waites \& Voglmayr, 1963), which should have occurred in rams under general anaesthesia (Godinho \& Setchell, 1975). However, the increase in flow of testicular blood observed in the present experiments might be due to the direct heating of the testes, that is to say to the exclusion of the scrotal skin from the heating.

The present and previous results reported on total testicular blood flow were in fact made up of both testicular and epididymal flows, as no ligation of the epididymal vessels was performed. However, the epididymal contribution is of little importance, representing $\approx 15 \%$ of total testicular flow in the anaesthetized ram (Setchell et al., 1964). Moreover, a distinct difference of both testicular and epididymal blood flow was produced in adult rats by induced cryptorchidism immediately after birth (Damber et al., 1985), and flows of testicular and epididymal blood were increased when the scrotum of anaesthetized rats was heated to $41^{\circ} \mathrm{C}$ or more (Waites et al., 1973; Damber \& Janson, 1978).

Previous studies of scrotal heating in rams have shown no change in capillary blood flow of the testes (Setchell et al., 1966; Godinho \& Setchell, 1975), although capillary blood flow was reported to increase in one strain of Merino ram more 'resistant' to heat (Fowler \& Setchell, 1971) or after one day of scrotal heating (Sand et al., 1971). The rise measured in total blood flow in the present study could therefore be due to increased shunting of the flow of blood through the arterio-venous anastomoses between the testicular artery and the pampiniform plexus, which has recently been described (Wensing et al., 1981; Hees et al., 1984; Noordhuizen-Stassen et al., 1985), as a result of heating. However, such an assertion requires simultaneous assessment of both capillary and total blood flows in the testis, and adequate techniques for repeated measurements of both values on the same animal are not yet available.

Our results on lymph flow also do not agree with the earlier observations of Cowie et al. (1964), who heated the scrotum, with the testes inside, of conscious rams to $\approx 40^{\circ} \mathrm{C}$ for up to 90 min and found substantial increases in lymph flow. Their results could be due to heating of the scrotal skin or to the lack of anaesthesia. In the present experiments, we deliberately chose the lower temperature for study, to simulate more closely the testicular temperatures observed in infertile men (Mieusset et al., 1987, 1989; Zorgniotti \& Sealfon, 1988) and in rams with insulated scrota or exposed to high environmental temperatures under field conditions.

Financial support for this project was provided by Cecos Midi-Pyrénées and Inserm U168 for R. Mieusset and by a small grant from the Australian Research Council.

\section{References}

Bratten, A.C. \& Marshall, E.K. (1939) A new coupling component for sulfanilamide determination. J. biol. Chem. 128, 537-550.

Cowie, A.T., Lascelles, A.K. \& Wallace, J.C. (1964) Flow and protein content of testicular lymph in conscious rams. J. Physiol. 171, 176-187.
Damber, J-E. \& Janson, P.O. (1978) The influence of scrotal warming on testicular blood flow and endocrine function in the rat. Acta Physiol Scand. 104, 61-67.

Damber, J-E., Bergh, A. \& Daehlin, L. (1985) Testicular blood flow, vascular permeability, and testosterone 
production after stimulation of unilaterally cryptorchid rats with human chorionic gonadotropin. Endocrinology 117, 1906-1913.

Fowler, D.G. \& Setchell, B.P. (1971) Selecting Merino rams for ability to withstand infertility caused by heat. 2. The effect of heat on scrotal and testicular blood flow. Aust. J. exp. Agric. anim. Hush. 11, [43 147.

Godinho, H.P. \& Setchell, B.P. (1975) Total and capillary blood flow through the testes of anaesthetized rams. J. Physiol. 251, 19P-20P.

Hees, H., Leiser, R., Kohler, T. \& Wrobel, K.H. (1984) Vascular morphology of the bovine spermatic cord and testis. 1. Light and scanning electron-microsopic studies on the testicular artery and pampiniform plexus. Cell Tiss. Res. 237, 31-38.

Laurie, M.S. \& Setchell, B.P. (1979) The continuous measurement of testicular blood flow in the ram, in relation to the pulsatile secretion of testosterone. $J$. Physiol. 287, 10P.

Mieusset, R., Bujan, L., Mondinat, C., Mansat, A., Pontonnier, F. \& Grandjean, H. (1987) Association of scrotal hyperthermia with impaired spermatogenesis in infertile men. Fert. Steril. 48, 1006-1011.

Mieusset, R., Bujan, L., Plantavid, M. \& Grandjean, H. (1989) Increased levels of serum FSH and LH associated with intrinsic testicular hyperthermia in oligospermic infertile men. J. clin. Endocrinol. Metab. 68, $419-425$.

Noordhuizen-Stassen, E.N., Charbon, G.A., de Jong, F.H. \& Wensing, C.J.G. (1985) Functional arterio-venous anastomoses between the testicular artery and the pampiniform plexus in the spermatic cord of rams. $J$. Reprod. Fert. 75, 193-201.

Sand, R.S., Dutt, R.H. \& Preston, D.F. (1971) Effect of local heating on ram testis blood flow. J. anim. Sci. 32, $391 \mathbf{P}$.

Setchell, B.P. (1978) Vascular supply and drainage of the testis. In The Mammalian Testis, pp. 50-76. Ed. B. P. Setchell. Elek Books, London.

Setchell, B.P. \& Brooks, D.E. (1988) Anatomy, vasculature, innervation and fluids of the male reproductive tract. In The Phy:siology of Reproduction, pp. 753-839 Eds E. Knobil \& J. D. Neill. Raven Press, New York.

Setchell, B.P., Waites, G.M.H. \& Till, A.R. (1964) Variations in flow of blood within the epididymis and testis of the sheep and rat. Nature, Lond. 203, $317-318$.

Setchell, B.P., Waites, G.M.H. \& Thoburn, G.D. (1966) Blood flow in the testis of conscious ram measured with krypton 85: effects of heat, catecholamines and acetylcholine. Circ. Res. 18, 755 765 .

Waites, G.M.H. (1961) Polypnea evoked by heating the scrotum of the ram. Nature, Lond. 190, 172-173.

Waites, G.M.H. (1962) The effect of heating the scrotum of the ram on respiration and body temperature. $Q$. J. exp. Physiol. 47, 314-323.

Waites, G.M.H. (1976) Temperature regulation in male and female mammals. Israel J. med. Sci. 9, 982-993.

Waites, G.M.H. \& Setchell, B.P. (1964) Effect of local heating on blood flow and metabolism in the testis of conscious ram. J. Reprod. Fert. 8, 339-349.

Waites, G.M.H. \& Setchell, B.P. (1990) Physiology of the mammalian testis. In Marshall's Physiology of Reproduction, Vol. 2, pp. 1--105. Ed. G. E. Lamming, Churchill Livingstone, London.

Waites, G.M.H. \& Voglmayr, J.K. (1963) The functional activity and control of the apocrine sweat glands of the scrotum of the ram. J. Reprod. Fert. 8, 339-349.

Waites, G.M.H., Setchell, B.P. \& Quinlan, D. (1973) Effect of local heating on the scrotum, testes and epididymides of rats on cardiac output and regional blood flow. J. Reprod. Fert. 34, 41-49.

Wensing, C.J.G., Djikstra, G. \& Frankenhuis, M.T. (1981) The intricate morphological relations between testicular artery and pampiniform plexus. Int. $J$. Androl. Suppl. 3, 77-78.

Zorgniotti, A.W. \& Sealfon, A.l. (1988) Measurement of intrascrotal temperature in normal and subfertile men. J. Reprod. Fert. 82, 563-567.

Received 10 December 1990 